\title{
OPIEKA KRAKOWSKIEGO TOWARZYSTWA DOBROCZYNNOŚCI NAD OŁTARZEM I OBRAZEM MATKI BOSKIEJ W BRAMIE FLORIAŃSKIEJ W XIX I NA POCZĄTKU XX WIEKU
}

\author{
Ewa Barnaś-Baran (D) http://orcid.org/0000-0001-8084-6150 \\ Uniwersytet Rzeszowski
}

\author{
ABSTRACT \\ THE CARE OF THE CRACOW CHARITABLE SOCIETY OVER \\ THE ALTAR AND PAINTING OF OUR LADY AT THE FLORIAN GATE \\ IN THE 19TH AND EARLY 20TH CENTURIES
}

The aim of this article is to present the actions taken by the Cracow Charitable Society in order to protect the altar and the painting in the Florian Gate. The image of Our Lady was handed over to the Society for care in 1817 , which it provided until the communist authorities disbanded the Society in 1951. In order to renovate the painting and altar, the Society mainly raised funds through public sacrifices and donations of individual people. Among the benefactors there were many affluent and well-known people from Cracow, as well as anonymous individuals. Source materials reveal that the image was revered both by the inhabitants of Cracow and its surroundings and that the religious services held there in the 19th century were infused with patriotic spirit. Next to the painting an alms box was placed for financial donations to the poor who were cared for by the Society - it had the highest income among all the poor boxes in Cracow. Today, the Florian Gate still houses an altar with a painting, which is currently under the care of the Daughters of Charity.

Keywords: Cracow Charitable Society, Florian Gate, charity, poor people.

Słowa kluczowe: Krakowskie Towarzystwo Dobroczynności, Brama Floriańska, dobroczynność, ludzie ubodzy. 


\section{WSTĘP}

W wieku XIX na terenie ziem polskich z inicjatywy ludzi świeckich, tworzono towarzystwa dobroczynne. Ich głównym zadaniem było niesienie pomocy ludziom ubogim przez zapewnienie im wyżywienia, ubrania, schronienia, a poprzez to ograniczenie liczby żebrzących. Akceptowaną formą wsparcia działalności towarzystw było udzielanie jałmużny przekazywanej ich członkom, wspomaganie darowiznami finansowymi i materialnymi, wpłacanymi składkami. Dochód przynosiły również skarbony (puszki) dla ubogich umieszczane w różnych częściach miast.

Dwa największe towarzystwa dobroczynne na ziemiach polskich na początku XIX wieku utworzono w Wilnie i Warszawie. W 1807 roku. powstało Wileńskie Towarzystwo Dobroczynności ${ }^{1}$, w 1814 roku powołano Warszawskie Towarzystwo Dobroczynności². Rok 1815 był czasem utworzenia Lubelskiego Towarzystwa Dobroczynności ${ }^{3}$ W 1816 roku powstało Krakowskie Towarzystwo Dobroczynności (dalej: KTD) ${ }^{4}$, którego celem było zmniejszenie liczby żebrzących w Krakowie oraz pomoc tym ubogim, którzy z racji wieku i złego stanu zdrowia nie mogli zapracować na utrzymanie. KTD obejmowało opieką ludzi ubogich, chorych, kalekich, zarówno starców, jak i dzieci, którzy pochodzili z miasta i gminy Kraków. Pośrednio wspomagano mieszkańców miasta, dążąc do ograniczenia, a nawet wyeliminowania żebractwa. Wszelkie działania miały służyć „dobru ludzkości”. Jednym z ważnych zadań KTD, chociaż nie deklarowanym bezpośrednio w celach istnienia Towarzystwa, była opieka nad ołtarzem i obrazem Matki Boskiej znajdującego się w Bramie Floriańskiej. Towarzystwo utrzymywało również staruszka (dziadka), który pilnował obrazu i skarbonki pod nim umieszczonej. Ofiary wrzucane do niej zasilały budżet KTD ${ }^{6}$.

1 Wiadomości o czynnościach Wileńskiego Towarzystwa Dobroczynności od czasu jego utworzenia do dnia 1 stycznia 1819 r. przez Sekretarza Towarzystwa Ignacego Jundzilta ułożona, Wilno 1819, s. 2; H. Markiewiczowa, Działalność Wileńskiego Towarzystwa Dobroczynności w początkach XIX stulecia, „Kultura i Edukacja” 1993, nr 3, s. 117-124.

${ }^{2}$ H. Markiewiczowa, Działalność wychowawczo-opiekuńcza Warszawskiego Towarzystwa Dobroczynności w latach 1814-1914, „Przegląd Historyczno-Oświatowy”, R. 33 [nr 2], 1990, s. 196-206.

${ }^{3}$ C. Kępski, Lubelskie Towarzystwo Dobroczynności (1815-1952), Lublin 1990; A. Puszka, Dziatalność opiekuńczo-wychowawcza Zakonu Sióstr Miłosierdzia Wincentego à Paulo w Lublinie w XIX i XX wieku, Lublin 2013, s. 97.

${ }^{4}$ Organizacja i ustawy Towarzystwa Dobroczynności Wolnego Miasta Krakowa, Kraków 1817, s. 8; J. Bąk, Opieka społeczna nad sierotami w Krakowskim Towarzystwie Dobroczynności w latach 18161916, „Rocznik Krakowski” 1975, t. 46, s. 99-112; R. Skowron, Towarzystwo Dobroczynności. Organizacja i działalność ogólnego domu schronienia ubogich na Wawelu (1816-1846), „Studia do Dziejów Wawelu", R. V, 1991, s. 479-496; E. Barnaś, Powstanie i pierwsze lata dziatalności Krakowskiego Towarzystwa Dobroczynności (1816-1820), „Zeszyty Naukowe WSP w Rzeszowie. Pedagogika. Psychologia" 1997, z. 3, s. 87-99; E. Barnaś-Baran, Działalność opiekuńcza Krakowskiego Towarzystwa Dobroczynności w latach 1919-1939, „Studia i Prace Pedagogiczne” 2015, nr 2, s. 224.

${ }_{5}^{5}$ Archiwum Narodowe w Krakowie (dalej: ANK), Protokół pierwszy posiedzeń Towarzystwa Dobroczynności w Krakowie od 1816 do 1827, sygn. 547/1 (dawna TD 7), Posiedzenie dnia 7 I 1817 r., k. 5.

${ }^{6}$ L. Cyfrowicz, Obraz Matki Boskiej i skarbonka ubogich w Bramie Floryańskiej w Krakowie, Kraków 1884, s. 28. 


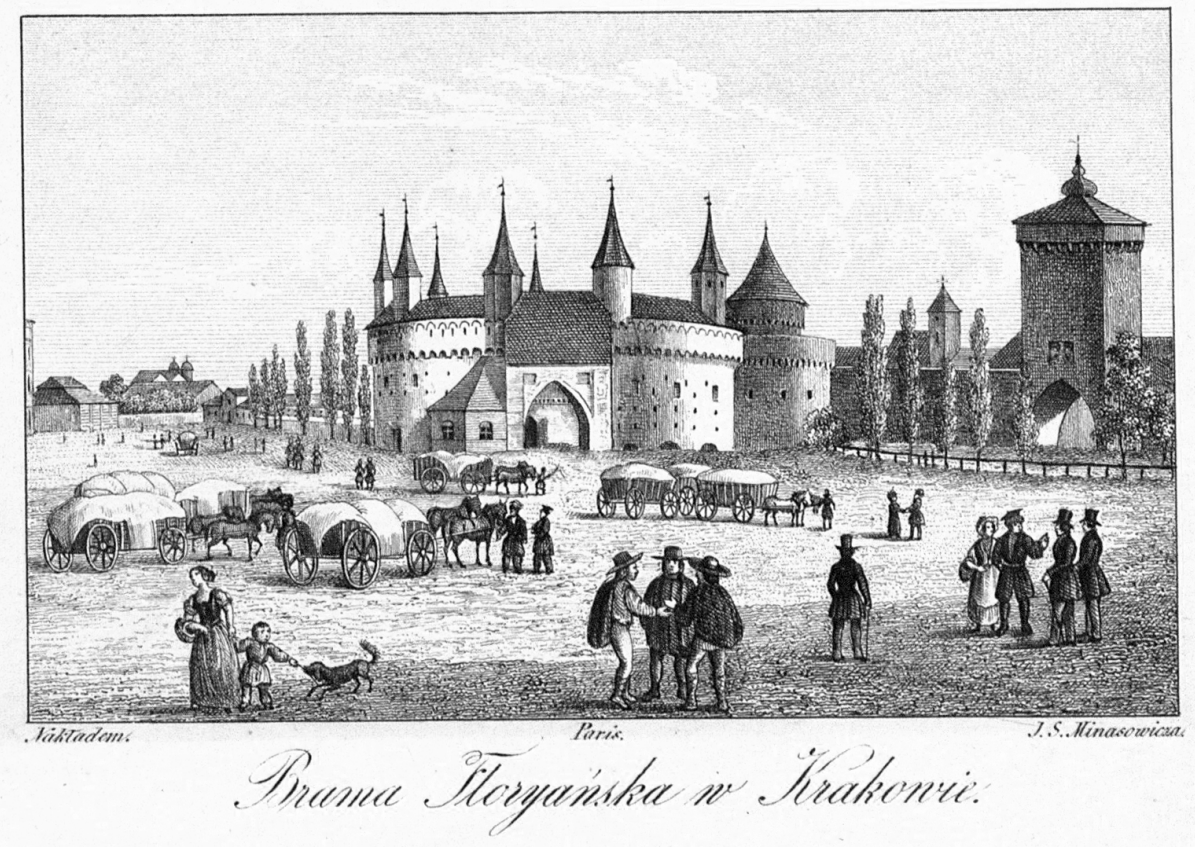

Il. 1. Brama Floriańska w XIX wieku

Źródło: Biblioteka Jagiellońska, Zbiory Specjalne, BJ Graf. 1. 8290, teka 142.

W artykule przedstawiono, w jaki sposób Krakowskie Towarzystwo Dobroczynności realizowało wymienione zadanie. Na podstawie analizowanych materiałów źródłowych odtworzono działania, jakie podejmowane były od 1817 do 1939 roku przez zarząd Towarzystwa, w celu zachowania w odpowiednim stanie obrazu i oftarza w Bramie Floriańskiej, gdzie przychodzili na modlitwę krakowianie oraz osoby przyjeżdżające do miasta i przechodzące przez Bramę Floriańską. Obraz ten otoczony był dużym szacunkiem mieszkańców Krakowa, a wiele osób, zanosząc modlitwy do Matki Boskiej, wspomagało jednocześnie finansowo podopiecznych Towarzystwa Dobroczynności pieniędzmi wrzucanymi do skarbony. Podjęte w artykule zagadnienie nie ma szerszego odzwierciedlenia w literaturze, wspomniał o nim o. Bronisław Panek, charakteryzując działalność krakowskich organizacji dobroczynnych w latach 1918-1939, uwagę obrazowi i działaniom KTD poświęciła Agnieszka Widacka-Bisaga, pisząc o recepcji wizerunków maryjnych w Polsce?

7 B. Panek, Krakowskie organizacje charytatywne w latach 1918-1939, Kraków 1986, s. 51; A. Widacka-Bisag a, Między pobożnościq a przesqdem. Matka Boska Piaskowa a fenomen cudownych wizerunków maryjnych w Polsce, Kraków 2013, s. 106-111; A. Swaryczew ski, Poludniowo-zachodni odcinek murów obronnych Krakowa, „Teka Komisji Urbanistyki i Architektury” 1975, t. IX, s. 25. Historia murów obronnych była już od połowy XIX w. tematem zainteresowań wielu badaczy. Zespół 
Materiały źródłowe, których analiza pozwoliła na opracowanie podjętego tematu, zgromadzone zostały w Archiwum Narodowym w Krakowie. Materiały rękopiśmienne obejmowały akta KTD oraz protokoły posiedzeń Rady Ogólnej Towarzystwa Dobroczynności za lata 1817-1919. Podstawowym źródłem były akta obrazu Matki Boskiej w Bramie Floriańskiej, znajdujące się w Zespole Krakowskiego Towarzystwa Dobroczynności ${ }^{9}$. Korzystano również z maszynopisu posiedzeń Rady Ogólnej za lata 1921-1940 ${ }^{10}$. Istotne treści zawierała publikacja Leona Cyfrowicza (1844-1904), członka KTD, sekretarza Towarzystwa ${ }^{11}$, analizie poddano Roczniki Krakowskiego Towarzystwa Dobroczynności z lat 1839-1918 ${ }^{12}$, informacje zaczerpnięto również z publikacji Józefa Teodora Głębockiego (1806-1886) ${ }^{13}$, członka KTD, sekretarza Towarzystwa oraz z pamiętnika wydanego w 50. rocznicę powołania Towarzystwa ${ }^{14}$. Pomocne były opracowania poświęcone zabytkom Krakowa, zwłaszcza pracom realizowanym w obrębie Bramy Floriańskiej ${ }^{15}$. W świetle analizowanych materiałów źródłowych można przyjąć, że obrazem w Bramie Floriańskiej KTD opiekowało się od 1817 roku do czasu rozwiązania go przez władze komunistyczne w $1951 \mathrm{roku}^{16}$. W materiałach źródłowych nie znaleziono informacji, aby od tego zadania odstąpiono po 1939 roku. Obecnie w Bramie Floriańskiej, która jak zaznaczył Jan Radwański - „stoi dla pamiątki jako niemy świadek natarczywości losu", nadal znajduje się ołtarz oraz obraz Matki Bożej ${ }^{17}$. Troszczą się o niego Siostry Szarytki z ulicy Warszawskiej 8. Zdaniem Widackiej-Bisagi historyczne

murów floriańskich z Barbakanem ma najliczniejszą literaturę, natomiast na temat ołtarza niewiele jest informacji.

${ }^{8}$ ANK, Krakowskie Towarzystwo Dobroczynności (dalej: KTD), zespół 547.

${ }^{9}$ ANK, Akta obrazu Matki Boskiej w Bramie Floriańskiej będącego pod opieką Towarzystwa Dobroczynności 1817-1945, sygn. 547/427.

${ }^{10}$ ANK, Protokoły posiedzeń z lat 1921-1940 r., sygn. 547/11 9 (dawna: TD 320), maszynopis.

${ }^{11}$ L. Cyfrowicz, op. cit.

12 Wydawnictwo zmieniało kilka razy swą nazwę. W 1818 r. nosiło tytuł Rocznik Towarzystwa Dobroczynności Wolnego Miasta Krakowa i Jego Okreggu; od 1821 r. - Rocznik Towarzystwa Dobroczynności Wolnego Miasta Krakowa; po 1846 r. - Rocznik Towarzystwa Dobroczynności Miasta Krakowa; od 1874 r. - Rocznik Krakowskiego Towarzystwa Dobroczynności. Poszczególne roczniki liczyły od kilkudziesięciu do dwustu stron.

${ }^{13}$ J.T. Głębocki, Zakłady ku ulżeniu cierpieniom bliźnich obecnie w Krakowie istniejace. Z krótka wzmianka o dawniejszych, a dziś nie istniejących instytucyach tego rodzaju, Kraków 1852.

${ }^{14}$ Pamiętnik Towarzystwa Dobroczynności Krakowskiego wydanym z powodu obchodzonego $w$ d. 24 i 25 czerwca 1866 r. pięćdziesiąt-letniego Jubileuszu wskrzeszenia w roku 1816 tegoż Towarzystwa, Kraków 1868.

${ }^{15}$ F. Kopera, Historya architektury, „Rocznik Krakowski” 1904, t. VI, s. 114; J. Pachoński, Dawne mury floriańskie. Zarys historyczny fortyfikacji i organizacji obrony miasta oraz przewodnik po wystawie „Dawne warownie Krakowa”, Kraków 1955.

${ }^{16}$ ANK, Urząd Wojewódzki Krakowski, Sygn. UW II 1098, k. 173. Rejestracja stowarzyszeń z terenu Krakowa 1945-1950 (1951), IV/3/Krm/39/45.

17 J. Radwański, O Bramie Floriańskiej i Serbach, Kraków 1832, s. 43; A. Grabowski, Dawne zabytki miasta Krakowa. Przypomnienia przeszłości o niektórych starożytnych zwyczajach mieszczan krakowskich. O bramach, basztach $i$ wszelakich tej niegdyś stolicy kraju obronach, z dodatkiem różnych do dziedziny pamiątek należących wiadomości. Z rękopisów zebrat i ogłosit Ambroży Grabowski, Kraków 1850, s. 34 . 
wiadomości o obrazie, początkach jego usytuowania w tak zwanej szyi, a następnie w Bramie Floriańskiej, znaleźć można w różnych materiałach: „Obejmują one mniej więcej lata 1694-1800 i uwypuklają raczej przejawy kultu i pobożności, niż świadectwa historyczne"18. Zaznaczyła zarazem, że udokumentowane dzieje datują się od 1817 roku, czyli roku przejęcia opieki nad obrazem i ołtarzem przez KTD. Jako interesujący przekaz można uznać legendy, które przywołane zostały w materiałach podejmujących temat obrazu Matki Boskiej z Bramy Floriańskiej, a także cudów będących dowodem jej pomocy i opieki nad mieszkańcami Krakowa. Przytaczane były one w publikacji Leona Cyfrowicza, Wacława Nowakowskiego (ks. Wacława z Sulgostowa), ks. Alojzego Fridricha ${ }^{19}$. Cyfrowicz w 1884 roku przypomniał również przekaz zamieszczony w kalendarzu wydanym w 1854 roku przez zakład księgarski Karola Wilda. Według staruszka z bramy Matka Boska ukazała się w „,...] przedbramiu kolistem (rotundzie), po prawej stronie, idąc od Kleparza. Sławiła się ona różnemi cudami, mianowicie obroną bramy, a szczególniej tem, że jej obraz wynoszono na miejsca pożarów trudnych lub niepodobnych do ugaszenia" ${ }^{20}$. Dalej przekaz dziadka z bramy mówił o tym, że w podziękowaniu za ratunek i pomoc w nieszczęściach odprawiane było nabożeństwo w kościele na Kleparzu u św. Floriana na cześć Matki Boskiej Pogornej (pożaru). Przekaz Nowakowskiego, w publikacji wydanej w 1902 roku, brzmiał następująco: „Obraz ten malowany na płótnie na wzór cudownego obrazu Matki Bożej u Karmelitów na Piasku. Matkę Bożą w tym obrazie zowią «Pogórną» (?)”21. W opinii Widackiej-Bisagi „od pogorzeli wywodzić należy przydomek Pogórna"22.

\section{KRAKOWSKIE TOWARZYSTWO DOBROCZYNNOŚCI}

Krakowskie Towarzystwo Dobroczynności, utworzone w 1816 roku, było jednym z najstarszych świeckich towarzystw dobroczynnych funkcjonujących na ziemiach polskich. Udzielało ono pomocy ludziom starym, chorym, kalekim, którzy nie mogli zarobić na swoje utrzymanie, wspomagało również sieroty, chłopców i dziewczęta. W zakładzie prowadzonym przez Towarzystwo, czyli Domu Schronienia Ogólnego, zapewniano im mieszkanie, wyżywienie, ubranie, a dzieciom umożliwiano ponadto zdobycie podstaw wykształcenia oraz przygotowanie do wykonywania pracy zarobkowej. Do pełnienia funkcji protektora Krakowskiego Towarzystwa Dobroczynności zapraszano biskupa krakowskiego, przewodniczył mu prezes wraz z Radą Ogólną.

${ }^{18}$ A. Widacka-Bisaga, op. cit., s. 109.

19 Przykłady legend przedstawiono w dalszej treści artykułu. W artykule posługiwano się nazwą Matka Boska, zgodnie z określeniem zawartym w materiałach źródłowych.

${ }^{20}$ L. Cyfrowicz, op. cit., s. 18-19.

${ }^{21}$ W. Nowakowski, O cudownych obrazach w Polsce Przenajświętszej Matki Bożej. Wiadomości historyczne, bibliograficzne i ikonograficzne. Przez X. Wacława z Sulgostowa, Kraków 1902, s. 289; A. Widacka-Bisaga, op. cit., s. 106-107.

22 A. Widacka-Bisaga, op. cit., s. 106-107. 
Rada była organem zarządzającym, który kierował pracą poszczególnych wydziałów Towarzystwa.

Starców, kaleki oraz sieroty przyjęte pod opiekę Towarzystwa Dobroczynności w Krakowie umieszczano w Domu Schronienia. Pierwotnie mieścił się on w jednym ze skrzydeł Zamku Wawelskiego, po 1846 roku podopieczni zostali zmuszeni przez wojska austriackie do opuszczenia zamku. Pomieszczenia zamieniono na koszary, a ubodzy od tej pory przebywali w kilku klasztorach krakowskich. Sytuację zmienił zapis Ignacego Rotarskiego w 1853 roku, w którym przeznaczył na potrzeby Towarzystwa dom przy ulicy Koletek 12, w dzielnicy Stradom. Na początku lat 80. XIX wieku podjęto budowę nowego domu dla podopiecznych w ogrodzie przylegającym do ulicy Koletek i w 1882 roku oddano go do użytku. W czasie I wojny światowej budynki częściowo zostały zajęte na potrzeby wojska. Należy wspomnieć, że po odzyskaniu przez Polskę niepodległości w 1918 roku Krakowskie Towarzystwo Dobroczynności nadal funkcjonowało. W latach 30. XX wieku wybudowano kolejną część zakładu Towarzystwa, do którego przyjmowano zubożałych mieszkańców Krakowa, część z nich przebywała tam, opłacając swój pobyt ${ }^{23}$. KTD nie przerwało działalności podczas II wojny światowej, zostało zlikwidowane decyzją władz komunistycznych w $1951 \mathrm{roku}^{24}$. Materialną pozostałością po Towarzystwie jest nadal istniejący gmach przy ul. Koletek 12. Obraz i ołtarz w Bramie Floriańskiej przez wiele lat stanowiły przedmiot opieki Rady Ogólnej, członków i Dam Towarzystwa Dobroczynności.

\section{OPIEKA KRAKOWSKIEGO TOWARZYSTWA DOBROCZYNNOŚCI NAD OŁTARZEM I OBRAZEM MATKI BOSKIEJ W XIX WIEKU}

Józef Kremer (1806-1875) ${ }^{25}$ w publikacji poświęconej cennym zabytkom Krakowa podał, że Brama Floriańska została zbudowana w 1498 roku za czasów króla Jana Olbrachta Jagiellona. Określając ją w 1870 roku mianem ,pomnik historyczny wysokiego dziejowego znaczenia”26, uzasadniał, że ,[...] przez cztery niemal stulecia

${ }_{23}$ Dzieje Krakowa. Kraków w latach 1918-1939, red. J. Bieniarzówna, J.M. Małecki, Kraków 1997, s. 278; E. Barnaś-Baran, Działalność opiekuńcza Krakowskiego Towarzystwa Dobroczynności w latach 1919-1939, „Studia i Prace Pedagogiczne”, R. 2, 2015, s. 222.

${ }^{24}$ ANK, Zespół KTD, Protokoły posiedzeń z lat 1921-1940 r., sygn. 11, 390 k.; Urząd Wojewódzki Krakowski, Sygn. UW II 1098, Rejestracja stowarzyszeń z terenu Krakowa 1945-1950 (1951), IV/3/ $\mathrm{Krm} / 39 / 45$, k. 173.

${ }_{25}$ Encyklopedia Krakowa, red. A.H. Stachowski, Kraków 2000, s. 507. Józef Kremer był bratem Karola Romana, filozofem, historykiem sztuki. Wykładał filozofię na UJ, kierował Katedrą Filozofii, pełnił funkcję rektora i prorektora UJ. Jego uczniem był m.in. Jan Matejko. Odegrał dużą rolę w życiu artystycznym, naukowym i kulturalnym Krakowa. Był przekonany, że należy opiekować się zabytkami, protestował przeciw wyburzaniu średniowiecznych murów obronnych miasta.

26 J. Kremer, Kraków wobec Polski i Sukiennice jego oraz stowo o Bramie Floriańskiej, Kraków 1870, s. 53. 
Brama Floryańska była wierną towarzyszką historyi naszego miasta i dziejów narodowych $[\ldots]^{\prime 27}$. Zamieszczając plastyczny opis wyglądu Bramy oraz wrażeń związanych z jej przekraczaniem, napisał:

Ta Matka Boża patrzała na długie szeregi pokoleń, które tędy przeszły. Pobożność ubrała wizerunek w kwiaty sztuczne, ale stroją go jeszcze inne, żywe, bo duchowe kwiaty, są to legendy ludu, powieści cudowne wiążące losy i dole miasta $\mathrm{z}$ tym wizerunkiem Matki Zbawiciela ${ }^{28}$.

Jak zaznaczył Nowakowski, w bramach miejskich zwyczajowo umieszczano obraz Matki Boskiej. Jako przykład podał Wilno, gdzie w bramach były obrazy, a najbardziej znany pozostał do dnia dzisiejszego wizerunek w Ostrej Bramie. Zaznaczył, że również w Krakowie podczas budowania tak zwanego rondla w połączeniu z Bramą Floriańską ustawiono obraz Matki Bożej. Podał, że: „Obraz cudowny Matki Bożej, obecnie będący w Floryańskiej Bramie, pierwotnie był w galeryi, łączącej bramę Floryańską z rondlem, tuż przy wejściu do rondla. Rondel ten i ta galerya wystawione były roku $1498^{\prime 2}$. W jego opinii obraz mógł być zniszczony przez Szwedów w 1655-1666. Wiadome było, że w 1755 roku rondel został odnowiony przez czuwającego nad stanem murów i basztami Krakowa Jana Zalewskiego. „Czy zaś wtedy namalowany, lub skądinąd wzięty - także nie wiadomo” - pisał autor ${ }^{30}$. Stwierdził, że pierwotny obraz nie mógł być malowany na płótnie. Ksiądz Alojzy Fridrich odnotował, że obraz znajdujący się w galerii łączącej rondel z bramą przeniesiono w 1834 roku i umieszczono w świeżo zbudowanym ołtarzu przy bocznej ścianie bramy i oddano go pod opiekę Towarzystwu Dobroczynności. Zaznaczył, że o początkach istnienia obrazu nic nie wiadomo, ale „szczególniejsze do niego nabożeństwo krakowian świadczy, że tu Matka Najświętsza łaskawie zwykła wysłuchiwać proszących"31. Przy obrazie modlono się zwłaszcza podczas oktawy Narodzenia Najświętszej Marii Panny, wieczorami śpiewano pobożne pieśni.

Ołtarzem i obrazem w Bramie Floriańskiej w XIX wieku, na podstawie upoważnienia Senatu Rządzącego Wolnego Miasta Krakowa, opiekowało się Krakowskie Towarzystwo Dobroczynności. Rozporządzenie zostało wydane dnia 8 marca 1817 roku (zarządzenie L. 627), zaś w dniu 17 marca 1817 roku reskrypt Nr 896 Wydziału Spraw Wewnętrznych tegoż Senatu potwierdził prawo Towarzystwa do opieki oraz pobierania datków dla ubogich ze skarbony. Została ona umieszczona przy ołtarzu, a przechodzące przez Bramę osoby mogły wrzucać do niej pieniądze, które zasilały dochody KTD. Na Towarzystwo nałożono natomiast obowiązek rozliczania się z zawartości skarbony i sposobu wykorzystania pieniędzy przed Wydziałem

${ }^{27}$ Ibidem, s. 55; S. Brzozowski, Józef Kremer jako pisarz, filozof i estetyk. Szkic krytyczny, Warszawa 1902, s. 24.

${ }^{28}$ J. Kremer, op. cit., s. 51.

${ }^{29}$ W. Nowakowski, op. cit., s. 289.

${ }^{30}$ Ibidem.

${ }^{31}$ Historye cudownych obrazów Najświętszej Maryi Panny w Polsce zebrat wedlug autentycznych źródet ks. Alojzy Fridrich T.J., tom drugi obejmujący obrazy dyecezyi krakowskiej, archidyecezyi lwowskiej, dyecezyi przemyskiej i tarnowskiej, Kraków 1904, s. 52. 


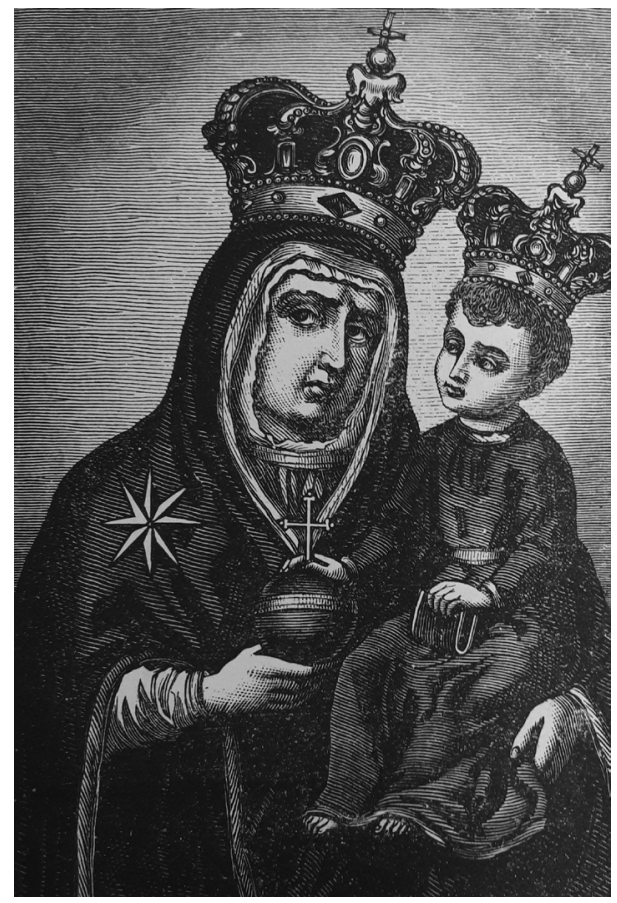

Il. 2. Obraz Matki Boskiej w Bramie Floriańskiej

Źródło: L. Cyfrowicz, Obraz Matki Boskiej i skarbonka ubogich w Bramie Floryańskiej w Krakowie, Kraków 1897, wyd. 2, s. 2.

Spraw Wewnętrznych ${ }^{32}$. Datki pochodziły przede wszystkim od przejeżdżających przez Bramę kupców. Wpływy zmniejszyły się już na początku lat 20. XIX wieku, jak sądzono w związku z mniejszą liczbą podróżujących. Do czuwania przy skarbonie wyznaczany był jeden z podopiecznych $\mathrm{KTD}^{33}$, starzec, który miał wkładać ofiary pozostawione poza skarboną do jej wnętrza. Ofiarujący najczęściej kładli pieniądze na desce, nie wrzucając ich do opieczętowanej skrzynki. Podejrzenie, że jedną z przyczyn obniżania się kwoty datków mogła być również niesumienność staruszka, potwierdziła Marianna Glińska, kobieta mieszkająca przy Bramie, która w liście z dnia 13 kwietnia 1822 roku opisała fakt wybierania przez staruszka pieniędzy ze skarbonki bez naruszania jej pieczęci ${ }^{34}$. W związku z tym zmieniono go na kolejnego

32 ANK, Akta obrazu Matki Boskiej w Bramie Floriańskiej będącego pod opieką Towarzystwa Dobroczynności 1817-1945, sygn. 547/427, k.1. Pismo Wydziału Spraw Wewnętrznych i Sprawiedliwości w Senacie Rządzącym Wolnego, Niepodległego i ściśle Neutralnego Miasta Krakowa i jego okręgu do prezesa KTD z 17 III 1817 r.; W rocznikach zamieszczano w dziale rozliczeń finansowych, w dochodach kwoty, jakie otrzymywało Towarzystwo z puszki w Bramie Floriańskiej. Encyklopedia Krakowa, s. 100.

${ }_{33}$ J. Radwański, O Bramie Floriańskiej i o Serbach, Kraków 1832, s. 45, 47; J.T. Głębocki, op. cit., s. 131; Pamiętnik Towarzystwa Dobroczynności Krakowskiego..., s. 82.

${ }^{34}$ ANK, Akta obrazu..., k. 5. Pismo do Rady Ogólnej Macieja Stummera z 21 IV 1822 r. 
starca „Marcina Wirta wypracowanego mosiężnika u Mosiężników”35. Towarzystwo troszczyło się również, aby przy obrazie utrzymywane było całodobowo oświetlenie. Jak już wspomniano, Towarzystwo wykorzystywało na własne cele składane przez dobroczyńców ofiary pieniężne, chociaż domyślano się, że lud wiejski przybywający do miasta nie tyle wspomagał podopiecznych KTD, ile przekazywał ofiarę na „światło dla obrazu"36. Część pieniędzy miała być przeznaczana na kwiaty i oświetlenie (lampki) obrazu ${ }^{37}$. Zasoby finansowe pochodzące ze skarbon umieszczonych w mieście oraz skarbony w Bramie Floriańskiej w XIX wieku wspomagały budżet Towarzystwa. Z tabeli zamieszczonej poniżej wynika, że kwoty zbierane do skarbony w Bramie Floriańskiej były dużo wyższe niż z pozostałych skarbon umieszczonych w Krakowie.

Tabela 1. Dochody ze skarbony w Bramie Floriańskiej w latach 1830-1891

\begin{tabular}{|c|c|c|}
\hline Rok & Skarbona w Bramie Floriańskiej & Dochód ogólny ze skarbon \\
\hline 1830 & $\begin{array}{c}318 \text { zł } 12 \text { gr (wraz ze skarboną w Domu } \\
\text { Schronienia KTD) }\end{array}$ & $833 \mathrm{zł} 20 \mathrm{gr}$ \\
\hline 1839 & $365 \mathrm{złp} 4 \mathrm{gr}$ & $828 \mathrm{zł} 19 \mathrm{gr}$ \\
\hline 1850 & $891 \mathrm{złp} 6 \mathrm{gr}$ & $6315 \mathrm{złp} 22 \mathrm{gr}$ \\
\hline 1860 & $1415 \mathrm{złp} 24 \mathrm{gr}$ & $1392 \mathrm{zła} 90 \mathrm{1} / 2 \mathrm{ct}$ \\
\hline 1875 & $374 \mathrm{zła} 88 \mathrm{ct}$ oraz $20 \mathrm{złp} 27 \mathrm{gr}$ & $693 \mathrm{zła} 5 \mathrm{ct}$ oraz $7 \mathrm{rsr} 42 \mathrm{kop}$ \\
\hline 1881 & $285 \mathrm{zła} 16 \mathrm{ct}$ oraz $3 \mathrm{rsr} 55 \mathrm{kop}$ & $552 \mathrm{zła} 25 \mathrm{ct}$ \\
\hline 1891 & $391 \mathrm{zła} 05 \mathrm{ct}$ & \\
\hline
\end{tabular}

Źródło: Rocznik XIII Towarzystwa Dobroczynności Wolnego Miasta Krakowa za rok 1830, Kraków 1831, s. 7; Rocznik XXII Towarzystwa Dobroczynności Wolnego Miasta Krakowa, Kraków 1841, s. 58-59; Rocznik Towarzystwa Dobroczynności Miasta Krakowa XXXII z roku 1850, Kraków 1851, s. 53; Rocznik Towarzystwa Dobroczynności Miasta Krakowa XLII z roku 1860, Kraków 1861, s. 50; Rocznik Krakowskiego Towarzystwa Dobroczynności LVII z roku 1875, Kraków 1876, s. 46, 47; Rocznik Krakowskiego Towarzystwa Dobroczynności LXIII z roku 1881, Kraków 1882, s. 55; Rocznik Krakowskiego Towarzystwa Dobroczynności LXXIII z roku 1891, Kraków 1892, s. 24, 25.

W skarbonie z Bramy Floriańskiej znajdowała się niemalże połowa dochodów ze wszystkich skarbon rozmieszczonych na terenie Krakowa, a należy zaznaczyć, że było ich kilkadziesiąt. Najwięcej pieniędzy zebrano w 1850 roku po tragicznym pożarze Krakowa, który w lipcu tego roku zniszczył znaczącą część miasta, pogłębiając problemy ludzi ubogich, dotykając również KTD. Kwota w skarbonie w Bramie Floriańskiej stanowiła wówczas $70 \%$ funduszów pochodzących z pozostałych skarbon. Był to porównywalny procent $\mathrm{z}$ zebranymi funduszami w 1891 roku. W pozostałych latach pieniądze ze skarbony w Bramie stanowiły około $40 \%$ dochodów ze skarbon

\footnotetext{
${ }^{35}$ Ibidem, k. 5.

${ }^{36}$ Ibidem, k. 13. Pismo z Senatu do KTD z 8 III 1817 r.

${ }^{37}$ L. Cyfrowicz, op. cit., s. 43.
} 
krakowskich. Najmniej datków, w porównaniu z pozostałymi skarbonami, odnotowano w 1860 roku. Kwestię dochodów ze skarbony podniósł Nowakowski (Wacław z Sulgostowa), wypowiadając się krytycznie na temat stanu kaplicy w bramie:

Z tej ofiary płynie znaczna pomoc; czyż nie wypadałoby z niej część użyć na uporządkowanie kaplicy, w której obraz zostaje, a która to kaplica w takiem zostaje niechlujnem zaniedbaniu, że wywołuje największe zgorszenie i oburzenie - $\mathrm{i}$ to zaraz na wstępie do Krakowa! ${ }^{38}$

W 1829 roku proponowano, aby przenieść obraz do framugi, która zostałaby wybita w pierwszej bramie od ulicy Floriańskiej, między filarami utrzymującymi wieżę $(\text { basztę) })^{39}$. Rada Ogólna wystosowała do Senatu prośbę o wyrażenie zgody na wybicie wnęki w celu umieszczenia tam obrazu, prace miały być wykonane na koszt KTD ${ }^{40}$. W dniu 19 grudnia 1829 roku uzyskano pozwolenie na przeniesienie obrazu ${ }^{41}$. Rada Ogólna KTD 3 stycznia 1830 roku upoważniła do podjęcia wspomnianych działań Kaspra Bieleckiego, przewodniczącego Wydziału Spisu. W realizacji tego zadania wspomagać go miał drugi członek KTD, a pierwszym krokiem było spotkanie z inspektorem budownictwa ${ }^{42}$. W związku z tym, że prace nie nabrały odpowiedniego tempa, Towarzystwo wyjaśniało Senatowi, dlaczego obraz nie został jeszcze przeniesiony. Wskazywano jako przyczynę opóźnienia złą kondycję stropu, który miał się znajdować nad obrazem. W opinii Rady Ogólnej należało ustalić, kto miał naprawić pokrycie nad Bramą Floriańską ${ }^{43}$. W piśmie z 7 września 1834 roku do Rady Ogólnej Bielecki relacjonował stan zaawansowania prac oraz poniesionych kosztów. Podał w nim, że zostało wymurowane z cegły sklepienie, zrobiony ołtarz z drewna, jak również pokryto czarną powłoką kapitaliki ram do obrazu. Praca murarska, malarska, ślusarska wyniosła około 692 złp $^{44}$. W maju 1835 roku Rada Ogólna zaniepokojona brakiem postępów w pracach prosiła o wyjaśnienie, dlaczego pomimo wyasygnowania łącznie kwoty 1000 złp w 1834 i 1835 roku ołtarz nie został ukończony. Do pomocy Bieleckiemu skierowano kolejne osoby, to jest Glogera i Stachowicza ${ }^{45}$. Po ponownej prośbie od Rady, w lipcu 1835 roku, Bielecki po raz kolejny wyjaśniał, dlaczego prace postępowały tak powoli ${ }^{46}$. Jako jedną z przyczyn podał zniszczenie obrazu.

${ }^{38}$ W. Nowakowski, O cudownych obrazach w Polsce Przenajświętszej Matki Bożej wiadomości historyczne, bibliograficzne i ikonograficzne. Przez X. Wactawa z Sulgostowa, Kraków 1902, s. 290.

39 ANK, Akta obrazu..., k. 17-18. Pismo do prezesa Kaspra Bieleckiego z dnia 27 VI 1829 r.; L. Cyfrowicz, op. cit., s. 30. W przypisie na stronie 46 Cyfrowicz podał, że pomysłodawcą argumentu obrony Bramy Floriańskiej przed zburzeniem, mówiącego, że wiatr będzie nawiewał nieczystości spoza murów, a przeciągi będą powiększać dolegliwości obywateli miasta, był sędzia pokoju okręgu II, Jan Librowski. Wniósł on pisemny protest na posiedzeniu Sejmu Rzeczypospolitej Krakowskiej w dn. 13 I 1827 r. Informacje te otrzymał Cyfrowicz od Żegoty Paulego. Za pomysłodawcę tego argumentu uważany jest senator Feliks Radwański.

${ }^{40}$ ANK, Akta obrazu..., k. 21. Pismo do senatu z KTD z 5 VII 1829 r.

${ }^{41}$ Ibidem, k. 29.

42 Ibidem, k. 35. Pismo do Kaspra Bileckiego przewodniczącego Wydziału Spisu KTD.

${ }^{43}$ Ibidem, k. 37. Pismo do Senatu z 5 VIII 1832 r.; k. 41. Pismo senatu z dnia 7 XI 1832 r.: ,przygotować kosztorys” i „wydać na ten cel stosowny awans”-, ,zaplanować środki finansowe”.

${ }^{44}$ Ibidem, k. 45. Pismo K. Bieleckiego do Rady Ogólnej z 7 IX 1834 r.

${ }^{45}$ Ibidem, k. 47. Pismo Rady Ogólnej do Kaspra Bileckiego z 24 V 1835 r.

${ }^{46}$ Ibidem, k. 5. Ponowna prośba Rady Ogólnej do Kaspra Bieleckiego z 28 VI 1835 r. 
Po wyjęciu go z ram okazało się, że musiał zostać oddany do odnowienia. Poinformował również, iż na zasuwie, która miała zamykać obraz, został wymalowany św. Florian ${ }^{47}$. Nadmienił, że pomoc Stachowicza ustała z niewiadomych przyczyn. Dnia 18 lipca 1835 roku obraz został uroczyście przeniesiony do Bramy Floriańskiej ${ }^{48}$.

Uroczystość odbyła się w obecności prezesa Senatu, urzędników, w mszy odbywającej się w Kościele Panny Marii uczestniczyli dostojni goście, przedstawiciele duchowieństwa, cechów. Obraz wystawiony był w głównym ołtarzu. Następnie odbyła się procesja, podczas której sześciu mieszkańców ubranych w stroje staropolskie niosło obraz. Po przybyciu do Bramy Floriańskiej obraz Matki Bożej ustawiono w odpowiednim miejscu. W procesji uczestniczyli thumnie mieszkańcy Krakowa, śpiewano pobożne pieśni. Po przeniesieniu obrazu odbyło się przyjęcie dla muzyków, śpiewaków, a koszty nie należały do niskich ${ }^{49}$.

Ze sprawozdania, jakie złożył Bielecki 26 lipca 1835 roku, wynika, że:

[...] rachunek za wykonane prace i użyte materiały, tj. materiały murarskie, praca murarska, prace stolarskie, prace ślusarskie i mosiężnicze, prace kamieniarskie, praca lakiernicza, praca malarza (odrestaurował obraz malarz Machuczka) i pozostałe koszty związane z dekoracją ołtarza, utrzymywaniem ładu i porządku itp. wyniosły 1463 złp $7 \mathrm{gr}^{50}$.

Kolejne prace restauracyjne nad ołtarzem w Bramie Floriańskiej podjęto pod koniec lat 50. XIX wieku. Na wniosek radcy KTD Ignacego Szulca Rada Ogólna wyznaczyła delegację w składzie Ignacy Szulc, Andrzej Karczyński i Jan Bizański, mającą ustalić, jaki był stan ołtarza ${ }^{51}$. Po kilku dniach złożono sprawozdanie z oględzin, stwierdzając, że konieczne było podjęcie prac konserwatorskich ${ }^{52}$. Zapoznano się z przygotowanym przez malarza Józefa Niedźwieckiego szczegółowym planem pracy i przygotowanym kosztorysem na kwotę $105 \mathrm{złp,} \mathrm{oraz} \mathrm{potwierdzono,} \mathrm{że} \mathrm{fak-}$ tycznie takie będą wydatki.

W latach 70. XIX wieku podjęto kolejne działania. W dniu 2 maja 1875 roku przedstawiono na posiedzeniu Rady Ogólnej relację z oględzin ołtarza. Odnotowano, iż:

[...] drzwi wymagały remontu, groziły one wypadnięciem i uszkodzeniem przechodzących tam ludzi. Rama, do której były przytwierdzone drzwi, też była z cienkich desek, drzwi były rozeschnięte i wskutek tego nie można ich było domykać. Przewidywano koszt napraw na $70 \mathrm{złr}$, ale zwrócono uwagę, że nie było to wiele w porównaniu z dochodami z puszki umieszczonej przy ołtarzu. Relację podpisał Wiktor Bylicki, przewodniczący Wydziału Ekonomiczego, a do podjęcia prac został upoważniony również Wydział Gospodarczy ${ }^{53}$.

${ }^{47}$ Ibidem, k. 55. Pismo do KTD od K. Bieleckiego z 12 VII 1835 r.; Obraz św. Floriana, który miał stanowić zasłonę obrazu Matki Boskiej, jak napisał Cyfrowicz, ,nie wiadomo kiedy zdjęto, lecz znajduje się nieuszkodzony w Domu Schronienia przy ul. Koletek”. L. Cyfrowicz, op. cit., s. 41.

${ }^{48}$ L. Cyfrowicz, op. cit., s. 40.

${ }^{49}$ Ibidem, s. 41.

${ }^{50}$ ANK, Akta obrazu..., k. 59. Sprawozdanie z poruczonych czynności przeniesienia Obrazu N.M. Panny Kaspra Bieleckiego z 26 VII 1835 r.

${ }^{51}$ Ibidem, k. 79. Pismo Rady Ogólnej do delegacji do odnowienia ołtarza w Bramie Floriańskiej z 18 IV 1859 r.

${ }^{52}$ Ibidem, k. 83. Pismo delegacji do Rady Ogólnej z 24 IV 1859 r.

${ }_{53}$ Ibidem, s. nlb. Relacja z oględzin ołtarza dnia 2 V 1875 r. 
Cyfrowicz odnotował, że na remont wydano wówczas 758 złp, prace nadzorował Jan Kanty Kaczmarski, przewodniczący Wydziału Spisu, pełniący następnie funkcję wiceprezesa $\mathrm{KTD}^{54}$.

Po upływie 20 lat z pisma prezesa KTD Władysława Ściborowskiego (1833-1903) dowiadujemy się, że Rada Ogólna w dniu 19 kwietnia 1895 roku podjęła decyzję dotyczącą odrestaurowania ołtarza w Bramie Floriańskiej. Osobą składającą wniosek był Henryk Schwarz, przewodniczący Wydziału Spisu ${ }^{55}$. Poproszono również o pomoc Annę Chlipalską, kobietę, która przez wiele lat bezinteresownie opiekowała się ołtarzem i dbała o porządek wokół niego. Ściborowski oraz dyrektor zakładu KTD Wojciechowski, składając podziękowania za jej zaangażowanie, zwrócili się z prośbą do mieszkańców Krakowa o zbieranie datków na remont ${ }^{56}$. Jak wynika z notatki podpisanej przez Cyfrowicza, zwrócił się on z prośbą o opinię dotyczącą wartości obrazu do konserwatora zabytków dra Stanisława Tomkowicza (1850-1933) ${ }^{57}$. Potwierdza ten fakt zamieszczona w aktach Towarzystwa odpowiedź konserwatora:

Obraz i ołtarz N.P. Maryi w Bramie Floriańskiej zbadałem. Przyszedłem do przekonania, że pod względem artystycznym $i$ archeologicznym ani jeden ani drugi wielkiej wartości nie przedstawia. Odnowienie ołtarzyka zapewne ograniczy się do odczyszczenia lub odświeżenia, przyczem wielkim zmianom nie ulegnie. Co do samego obrazu, radziłbym odrestaurowanie jego powierzyć p. Abramowiczowi ${ }^{58}$ (Grodzka 9, III piętro), który przy odczyszczeniu może potrafi zdjąć wierzchnią warstwę farb i dojść do pierwotnego malowania, a w każdym razie umiejętnie przy tem postąpi. Ścianę framugi wartałoby pomalować kolorem kamiennym, a nie czerwonym jak jest obecnie ${ }^{59}$.

Zbierane składki przez kobietę opiekującą się obrazem, nazwiskiem Chlipalska (vel Skublowa), na odnowienie obrazu przedstawiały kwotę 85 zł i 15 centów oraz 100 franków w złocie podarowane przez hrabinę Stanisławową Tarnowską. W jej opinii należało również przenieść obraz na lewą stronę niszy bramy, idąc od Rynku. Miała ona w tej kwestii porozumieć się z księciem Władysławem Czartoryskim $(1828-1894)^{60}$, ale nie otrzymała odpowiedzi. Konieczność zmiany uzasadniano tym,

${ }^{54}$ L. Cy frowicz, op. cit., s. 43.

${ }_{55}$ ANK, Akta obrazu..., s. nlb. Pismo z dn. 13 IV 1895 r.

${ }^{56}$ Ibidem, s. nlb. Podziękowanie pani Annie Chlinalskiej (Chlipalskiej) z dn. 17 VI 1895 r.; Pismo zatytułowane Brama Floriańska z 4 XII 1896 r. Podano w nim, że Chlipalska (obecnie Stublowa) zebrała ze składek 35 zł i 15 ct i 100 franków w złocie (od hr. Tarnowskiej). Od pani Szarskej otrzymano 50 zł razem 85 zł 15 ct i 100 franków.

${ }^{57}$ Ibidem, s. nlb. Pismo zatytułowane Brama Floriańska z 4 XII 1896 r.

${ }^{58}$ Encyklopedia Krakowa, s. 1. Bronisław Abramowicz (1837-1912), malarz, konserwator dzieł sztuki. Prawdopodobnie uczył się kompozycji u Jana Matejki, malował obrazy o tematyce historycznej, sceny rodzajowe, wizerunki świętych. Odnawiał obrazy w Muzeum Czartoryskich, malowidła ścienne w Sukiennicach, zapiecki stall w kościele Mariackim.

${ }^{59}$ ANK, s. nlb. Akta obrazu..., s. nlb. Pismo z 22 VII 1895 r. do Profesora od dra St. Tomkowicza.

${ }^{60}$ M. Kukiel, Czartoryski Władysław, ksiązę (1828-1894) [w:] Polski Stownik Biograficzny, 1938, t. IV, s. 300-303. Małgorzata Reinhard-Chlanda podała, że: „Czartoryski od początku nosił się z zamiarem urządzenia kaplicy na piętrze Bramy Floriańskiej, o czym zaświadcza podanie wystosowane do władz miasta w 1875 r., a także niezrealizowany projekt schodów zewnętrznych Filipa Pokutyńskiego. We wnętrzu kaplicy książę pragnął umieścić późnobarokową kopię cudownego obrazu Matki Boskiej 
że ludzie przychodzący na modlitwę narażeni byli na niebezpieczeństwo ze strony przejeżdżających dorożek i tramwaju konnego ${ }^{61}$. Ponieważ ruch w mieście wzrastał, a tramwaj przejeżdżał przez Bramę ${ }^{62}$, postępowało również zniszczenie ołtarza, co powodowało konieczność jego odnowienia.

Cyfrowicz proponował przeniesienie ołtarza w inne miejsce, w odpowiedniejsze warunki. W jego opinii należało powołać komisję dla rozstrzygnięcia i przedstawienia problemu Radzie Ogólnej KTD. W dniu 7 grudnia 1896 roku została ona powołana, jej zadaniem było zaplanowanie i wykonanie prac restauracyjnych. Zaproszono do niej Cyfrowicza, Biesiadeckiego i Jacka Matusińskiego ${ }^{63}$. Komisja zwróciła się z prośbą o rady i pomoc do konserwatora zabytków. Wspomniana składkowa kwota została wpłacona na książeczkę kasy oszczędności ${ }^{64}$.

Pod koniec XIX wieku umieszczona przy obrazie skarbona nadal stanowiła istotne źródło dochodów dla Towarzystwa. Jak wynika z tabeli 2, wpływy ze skarbony w latach 80. i 90. XIX wieku nadal utrzymywały się na poziomie kilkuset złotych austriackich.

Jak wskazują powyższe dane, w poszczególnych latach kwoty przekazywane przez ludność mieszkającą i odwiedzającą Kraków wrzucane do skarbony były podobne. Najniższe datki zebrano w 1889 roku, najwyższe zaś w 1891 roku. Kwoty te zawsze wynosiły kilkaset złotych austriackich.

W wydanej w latach 80. XIX wieku broszurze poświęconej ołtarzowi i obrazowi Matki Boskiej w Bramie Floriańskiej Cyfrowicz zaprezentował, w jaki sposób KTD wywiązywało się z powierzonego mu zadania opieki nad nimi. Z treści wynikało, że starano się dbać o obraz i porządek wokół ołtarza. Ubogiemu, staruszkowi, który tam czuwał, Rada Ogólna wynajmowała mieszkanie w rondlu Bramy Floriańskiej. O wszelkie akcesoria ołtarza troszczyła się jedna z Dam Towarzystwa Dobroczynności, w jej posiadaniu był również kluczyk do szuflady, w której przechowywano wota darowane przez modlących się. Wota były bardzo skromne, między innymi koraliki, obrazki, bransoletki, cenniejsze były nieliczne, należały do nich złote kolczyki, złoty pierścionek. Na bocznych ścianach ołtarza wisiało dziewięć obrazów, które, jak podał Cyfrowicz, nie miały wartości artystycznej, a przedstawiały Matkę Boską, Chrystusa

Piaskowej z kościoła Karmelitów, znajdującą się pierwotnie w szyi Barbakanu, a od 1834 roku w ołtarzu przejścia dolnego Bramy”. Eadem, Witraż w kaplicy Bramy Floriańskiej, „Rocznik Krakowski” 2008, t. 74, s. 195. Autorka zaznaczyła również, że wieloletnie zabiegi o aprobatę tej zmiany prawnego właściciela, czyli KTD, nie zakończyły się wyrażeniem zgody.

${ }^{61} \mathrm{~W}$ związku z uruchomieniem linii tramwajowej, która miała przechodzić pod Bramą, planowano jej rozebranie. Tramwaj nie mieścił się w niej, ale ostatecznie postanowiono pogłębić przejazd i Bramę pozostawiono.

${ }^{62}$ J. Kołodziej, Krakowskie tramwaje, Rybnik, 2010, s. 8. Tramwaj konny 1882-1901. Na znaczenie tramwaju konnego dla prestiżu miasta autor zwracał uwagę, że na taką nowość mogło pozwolić sobie jedynie zamożne i rozwijające się miasto. Umiejscowienie trasy tramwaju dla znajdującego się w Bramie ołtarza nie należało jednak do korzystnych rozwiązań.

${ }^{63}$ Encyklopedia Krakowa, s. 598. Jacek Matusiński (przełom XIX i XX w.), budowniczy, który przebudował m.in. kamienicę Pod Złotym Karpiem przy Rynku Głównym 10, Dom Jana Matejki, wzniósł neogotycki kościół Matki Bożej Niepokalanie Poczętej przy ulicy Piekarskiej, prowadził budowę szpitala Bonifratrów.

${ }^{64}$ ANK, s. nlb. Pismo zatytułowane Brama Floriańska z 4 XII 1896 r. 
Tabela 2. Dochody ze skarbony w Bramie Floriańskiej za lata 1883-1894

\begin{tabular}{|c|c|}
\hline Rok & Kwota datków w skarbonie \\
\hline 1883 & 343 zła 60 ct \\
\hline 1884 & 331 zła 41 ct \\
\hline 1885 & 341 zła 57 ct \\
\hline 1886 & 334 zła 79 ct \\
\hline 1887 & Brak danych \\
\hline 1888 & 266 zła 76 ct \\
\hline 1889 & 196 zła 66 ct \\
\hline 1890 & 259 zła 63 ct \\
\hline 1891 & 391 zła 05 ct \\
\hline 1892 & 362 zła 73 ct \\
\hline 1893 & 363 zła 92 ct \\
\hline 1894 & 351 zła 69 ct \\
\hline
\end{tabular}

Źródło: Akta obrazu Matki Boskiej w Bramie Floriańskiej będącego pod opieką Towarzystwa Dobroczynności 1817-1945, sygn. 547/427.

i kilku świętych ${ }^{65}$. Zaznaczył, że szczególną opieką ołtarz otaczała żona wiceprezesa KTD Józefa Patelskiego, Julia z Czyżewskich Patelska. Często z własnych funduszy pokrywała wydatki na potrzebne do ołtarza przybory, na przykład firanki, obrusy ${ }^{66}$. Według Cyfrowicza o obrazie niewiele pisano do lat 80. XIX wieku. Pomimo prowadzonych skrupulatnych poszukiwań nie udało się ustalić ani malarza, ani daty jego powstania. Zaznaczył, że pewną datą jest rok 1817, kiedy KTD przejęło opiekę nad nim. Przywołał on opinię prof. Władysława Łuszczkiewicza, którego zdaniem obraz ten był jednym z wielu, które w Polsce na wzór Matki Boskiej Częstochowskiej malowano w XVII i XVIII wieku. Nie był jednak wierną kopią, ponieważ różniła go wysokość postaci Jezusa, sposób przedstawienia głów, korony były barokowe, malowane i złocone. Tło i korony były ciemne, gładkie, aczkolwiek Cyfrowicz, przywołując opinię znawcy, nadmienił, że obraz był przed kilkudziesięcioma laty cały na nowo przemalowany. Podobieństwo do wizerunku Matki Boskiej Częstochowskiej zanegował Nowakowski, krytykując Cyfrowicza za to porównanie i podając, że była to kopia „Matki Bożej u Karmielitów na Piasku”67.

Przypomniał, że z obrazem wiązały się liczne legendy. W każdej z nich zaznaczano, że był on cudowny, a pomoc Matki Boskiej niejednokrotnie ratowała Kraków i jego mieszkańców ${ }^{68}$. W podziękowaniu za łaski szczególnie licznie gromadzili się

${ }^{65}$ L. Cy frowicz, op. cit., s. 42.

${ }^{66}$ Ibidem, s. 43.

${ }^{67}$ W. Nowakowski, op. cit., s. 289.

${ }^{68}$ A. Fridrich, op. cit., s. 53-54; W. Nowakowski, op. cit., s. 289; A. Widacka-Bisaga, op. cit., s. $107-108$. 
Krakowianie w nabożeństwach odbywających się przy obrazie w czasie oktawy Narodzenia Najświętszej Marii ${ }^{69}$. Z czasów konfederacji barskiej datuje się legenda, w której ważną rolę odegrał jeden z mieszkańców Krakowa spieszący do obrony miasta przed atakującymi Rosjanami ${ }^{70}$. Był to rzemieślnik Marcin Oracewicz, który chciał wspomóc nieliczną załogę broniącą bramę w czerwcu 1768 roku:

Zorientowawszy się, że nie zabrał ze sobą amunicji, oderwał guzik od ubrania i stanąwszy przed obrazem Matki Boskiej poprosił o wsparcie. Guzik okazał się tak znakomitym nabojem, że poniósł śmierć od niego dowódca wojsk rosyjskich generał Panin, krewny księcia generała Repnina. Wskutek tego atakujące wojska odstąpiły. Co istotniejsze zarówno Moskale, jak i obrońcy widzieli postać Matki Boskiej. Dzięki Jej opiece również nie został zgładzony Oracewicz przez dążących do pomszczenia śmierci Panina. W nocy zobaczył postać Matki Boskiej, która poradziła mu ucieczkę ratującą życie. Po kilku latach powrócił do Krakowa, a w dowód wdzięczności otrzymał od magistratu dwa sklepy, w których sprzedawał swoje pasamonicze wyroby. Do końca życia cieszył się również ogromnym szacunkiem mieszkańców Krakowa ${ }^{71}$.

Druga legenda ukazywała, jakim szacunkiem darzono obraz. Po ośmiu dniach od wyżej opisanego zdarzenia przed obrazem modlił się przejeżdżający przez bramę marszałek konfederacji wojsk krakowskich Michał na Czarnocinie Czarnocki. Prosił, zdjąwszy czapkę z głowy, o pomoc Matki Boskiej i modlił się, a koń, na którym siedział, klęczał tak długo, dopóki marszałek nie zakończył modlitwy ${ }^{72}$.

Kolejna legenda ukazywała konsekwencje znieważenia obrazu Matki Boskiej przez przejeżdżającego konno adiutanta generalskiego wojsk rosyjskich.

W dniu 3 VIII 1879 r. wojsko opuszczało miasto i przechodziło przez Bramę Floriańską. Adiutant siedząc na koniu dobył szabli i przeciął koronę z kwiatów, która zdobiła głowę Matki Boskiej. Przerażeni zgromadzeni tam mężczyźni nie mieli odwagi się odezwać. Zrobiła to jedna staruszka, która miała, jak sama mówiła, przynajmniej 120 lat. Siedziała tam żebrząc przy obrazie. Zawołała ona do złoczyńcy, że pozna skutki swojego czynu. Okazało się już po chwili, że zaledwie kilkanaście kroków za bramą ziemia rozstąpiła się i żołnierz wraz z koniem wpadli w szczelinę. Pomocy udzielili mu inni żołnierze, ratując go, natomiast koń wpadł w przepaśćc ${ }^{33}$.

${ }^{69}$ Ibidem, s. 20-21. W 1862 r. Komisja Namiestnicza zażądała od władz diecezjalnych wydania stosownych rozporządzeń i zabronienia gromadzenia się i śpiewania pieśni przy obrazie w czasie oktawy Narodzenia Najświętszej Panny Marii. Poprzez to przerwano tradycję uroczystego wspominania zwycięstwa króla Jana III Sobieskiego nad Turkami 12 IX 1683 r., którą Papież Innocenty XI i Pius VII zalecili obchodzić w czasie wymienionej oktawy. Prezes KTD zmuszony był do wydania decyzji o wcześniejszym zamykaniu obrazu, tj. o 18.00 (trzy godziny wcześniej).

${ }^{70}$ W. Nowakowski, op. cit., s. 289.

${ }^{71}$ L. Cyfrowicz, op. cit., s. 14-15.

72 Zob. A. Fridrich, op. cit., s. 54; L. Cyfrowicz, op. cit., s. 14; A. Widacka-Bisaga, op. cit., s. 108.

${ }^{73}$ L. Cyfrowicz, op. cit., s. 17. 


\section{DZIAŁANIA KRAKOWSKIEGO TOWARZYSTWA DOBROCZYNNOŚCI NA RZECZ OCHRONY OŁTARZA OBRAZU MATKI BOSKIEJ W BRAMIE FLORIAŃSKIEJ W XX WIEKU}

Na początku XX wieku podjęto kolejne prace stolarskie przy ołtarzu. Fundusze na ten cel KTD starało się pozyskiwać poprzez zbiórki, uzyskiwano pieniądze ze sprzedaży broszurek, apelowano o darowizny do indywidualnych osób ${ }^{74}$. W dniu 10 lutego 1907 roku Rada Ogólna złożyła podziękowania Kazimierzowi Jachimowiczowi, który odnowił ołtarz według wskazówek Jacka Matusińskiego oraz odmalował framugę. Koszty reperacji ołtarza wyniosły 555 koron. W październiku 1907 roku proszono Władysława Pochwalskiego, aby po zakończonych już pracach nad odnowieniem ołtarza zajął się odnową obrazu i umieszczeniem go w ołtarzu. Jak wynika z pisma, praca została wykonana bezinteresownie ${ }^{75}$.

W odrodzonej Polsce KTD kontynuowało tradycję opieki nad obrazem Matki Boskiej umieszczonym w ołtarzu w Bramie Floriańskiej w Krakowie. Przy ołtarzu nadal służbę pełnili wyznaczeni staruszkowie z zakładu, kwestując na rzecz Towarzystwa. Na posiedzeniu Rady Ogólnej w dniu 16 września 1926 roku ówczesny prezes KTD Kazimierz Wacławowicz przedstawił treść listu napisanego przez członka honorowego KTD, wieloletniego wiceprezesa Towarzystwa dra Ludwika Schneidera. Wyrażał w nim gotowość odnowienia Ołtarza w Bramie Floriańskiej i pokrycia z własnych funduszy kosztów tych działań. Rada Ogólna, w składzie Kazimierz Wacławowicz, dr Wiktor Gajewski, ks. dr Stanisław Domasik, dr Adam Klimała, Julian Kwieciński, dr Ignacy Masny, Karol Orlecki, dr Julian Walter, ustosunkowała się pozytywnie do tego projektu, wyrażając podziw dla dobroczyńcy i jego gotowości wsparcia KTD w opiece nad ołtarzem ${ }^{76}$. Jak wynika z zapisu w protokole z posiedzenia Rady Ogólnej Towarzystwa Dobroczynności w Krakowie, które odbyło się dwa lata później, to jest 29 października 1928 roku, osoby, które jednak nie chciały być wymieniane z nazwiska, odnowiły obraz Matki Boskiej, który zamieszczony był w ołtarzu w Bramie Floriańskiej ${ }^{77}$. W latach 1935-1936 realizowane były przez miasto prace renowacyjne Bramy Floriańskiej pod kierunkiem architekta Andrzeja Krzyżanowskiego $^{78}$. W związku z tymi działaniami zarząd KTD kontaktował się ze Schneiderem, który w 1926 roku deklarował chęć finansowania odnowienia ołtarza. W piśmie Ludwika Schneidera z 27 sierpnia 1935 roku, które przysłał z Baden, adresowanym do ówczesnego prezesa KTD Kazimierza Wacławowicza, możemy przeczytać, że

${ }^{74}$ ANK, Akta obrazu..., s. nlb. Pismo informujące, że dyrektor Wojciechowski za sprzedane książeczki o Matce Boskiej uzyskał 10 koron i wpłacił do kasy. Dnia 11 IV 1907 r. - wpłacono je na książeczkę kasy oszczędności; Włodzimira Szołajaska złożyła 50 koron na restaurację obrazu 4 II 1907 r.

${ }^{75}$ Ibidem, s. nlb. Pismo RO do Władysława Pochwalskiego z dn. 9 X 1907 r.

${ }^{76}$ ANK, Zespół KTD, Protokoły posiedzeń z lat 1921-1940 r., sygn. 547/11 (dawna: TD 320), k. 281. Protokół posiedzenia Rady Ogólnej Towarzystwa Dobroczynności odbytego dnia 16 IX 1926 r.

77 Ibidem, k. 144. Protokół z posiedzenia Rady Ogólnej Towarzystwa Dobroczynności w Krakowie odbytego w dniu 29 X 1928 r. w Sali Magistratu.

${ }^{78}$ M. Reinhard-Chlanda, op. cit., s. 199. 
potwierdzał on swą decyzję. Miała to być forma podziękowania za opiekę Matki Boskiej oraz otrzymane łaski, a zwłaszcza pomoc w czasie choroby i przywrócenie zdrowia $^{79}$. Rada Ogólna nie tylko wyraziła zgodę na podjęcie czynności, ale okazała również uznanie dla tego zamiaru ${ }^{80}$.

Jak wskazują materiały źródłowe, kolejny etap działań KTD związanych z realizacją obowiązku opieki nad ołtarzem i obrazem w Bramie Floriańskiej przypadł na połowę lat 30. XX wieku. W dniu 10 listopada 1935 roku Rada Ogólna wystosowała pismo do Zarządu Miasta Krakowa, przypominając, że KTD było formalnym opiekunem obrazu od 1817 roku $^{81}$. Podkreślono również fakt, że Towarzystwo przy ołtarzu utrzymywało skarbonę do zbierania jałmużny. Poinformowano przy tym, że dr Schneider wyraził gotowość pokrycia kosztów jego odnowienia. Dążąc do upowszechnienia wśród mieszkańców Krakowa wiadomości o zaangażowaniu Towarzystwa w odnowienie ołtarza i obrazu, zarząd KTD podjął decyzję o wystosowaniu notatki do „Głosu Narodu” i „Ilustrowanego Kuriera Codziennego" w niej o wieloletniej opiece KTD nad ołtarzem. Proszono również o podanie komunikatu dotyczącego udziału Towarzystwa, a zwłaszcza Schneidera w odnowieniu ołtarza. Pismo prezesa KTD było wystosowane również w związku z przygotowywanym do druku w „Ilustrowanym Kurierze Codziennym” artykułem, w którym podjęto temat zakończenia remontu Bramy Floriańskiej. Artykuł ukazał się w dniu 5 sierpnia 1936 roku, w jego treści nie zostały zawarte informacje dotyczące $\mathrm{KTD}^{83}$.

W aktach obrazu Matki Boskiej znajdujemy także niedatowane pismo skierowane do Towarzystwa od osoby odnawiającej obraz. Napisano w nim, że prace objęły usunięcie niepotrzebnie naniesionych poprzednio warstw farby, odkrycie koron i pokrycie ich i ozdób na nowo prawdziwym złotem, ,aby obraz był odświeżony, a jednak nie stracił nic na swej starożytności”. Podano, że przesłano fotografie obrazu, które wykonała Matka Przełożona Sióstr Duchaczek. Proponowano również w piśmie,

79 ANK, Akta obrazu..., s. nlb. Pismo Ludwika Schneidera z 27 VIII 1935 r. z Baden.

${ }^{80}$ Ibidem, Akta obrazu..., s. nlb. Pismo do Ludwika Schneidera z 16 IX 1935 z podziękowaniem i upoważnieniem do podjęcia czynności wokół odnowienia Bramy.

${ }^{81}$ Ibidem, s. nlb. Pismo do Zarządu Miejskiego miasta Krakowa z 10 IX 1935 r.

${ }^{82}$ Ibidem, s. nlb. Pismo Kazimierza Wacławowicza do redakcji Głosu Narodu i Ilustrowanego Kuriera Codziennego z 4 VIII 1936 r.; A. B ańdo, ,Ilustrowany Kurier Codzienny” - pierwsze nowoczesne polskie pismo masowe [w:] Ilustrowany Kurier Codzienny. Ksiegga pamiatkowa w stulecie powstania dziennika i wydawnictwa 1910-1939, red. G. Wrona, P. Borowiec, K. Woźniakowski, Kraków 2010, s. 7. Koncern funkcjonował w latach 1910-1939; A. Bańdo, Nie tylko krew na pierwszej stronie. Problematyka kulturalna na łamach ,Ilustrowanego Kuriera Codziennego” w latach 1918-1939, Kraków 2006, s. 7. Autor podał, że Ilustrowany Kurier Codzienny (IKC) był jednym z najpotężniejszych koncernów wydawniczych II RP. Można zatem przyjąć, że wysłanie tam informacji o opiece KTD nad obrazem i ołtarzem miało na celu upowszechnienie, a zarazem przypomnienie tego faktu wśród czytelników. P. Borowiec, Jesteśmy głosem milionów. Dzieje krakowskiego wydawnictwa i koncernu prasowego Ilustrowany Kurier Codzienny (1910-1939), Kraków 2005, s. 101. IKC, zdaniem autora, oddziaływał zarówno na chłopa, robotnika, jak i inteligenta, uczulając wszystkich na losy dziedzictwa kultury, zabytków, pamiątek.

${ }^{83}$ Uroczyste zamknięcie kuli z Bramy Floriańskiej, „Ilustrowany Kurier Codzienny”, 5 VIII 1936, nr 216, s. 17-18. 
żeby wykonać obrazki, które Towarzystwo mogłoby sprzedawać przy Bramie lub w swojej siedzibie.

We wrześniu 1937 roku podjęto ponownie dyskusję nad kwestią restauracji ołtarza w Bramie Floriańskiej. Prezes KTD Kazimierz Wacławowicz wyjaśnił, że obraz Matki Boskiej oraz ołtarz zostały już odnowione, a także sprawiono nową mensę do ołtarza. Przedstawił zarazem korespondencję w tej sprawie ze Schneiderem. Stwierdził przy tym, że przedłużający się remont Bramy Floriańskiej uniemożliwiał przez dłuższy czas umieszczenie w niej odnowionych elementów ${ }^{84}$. Na zebraniu obecni byli członkowie Rady Ogólnej w składzie ks. prałat Zygmunt Kulig, dr Wiktor Gajewski, dr Adam Klimała, Julian Kwieciński, dr Jan Mach, dr Ignacy Masny, Karol Orlecki, Jan Szwaja, dr Julian Walter. Zabierając głos, podkreślali, że sytuacja ta wywoływała zaniepokojenie, jak określono „katolickiej ludności miasta”, która kierowała zapytania o ołtarz i obraz do Towarzystwa Dobroczynności. Zaznaczono, że mieszkańcy Krakowa mieli do obrazu „szczególne nabożeństwo" 85 , a niemalże każdy przybywający do Krakowa, przechodząc przez Bramę Floriańską, oddawał cześć Matce Boskiej, prosił o opiekę, przystając na modlitwę. Tak samo krakowianie darzyli wizerunek Matki Boskiej dużym szacunkiem i wyrażali niezadowolenie z powodu uniemożliwionej adoracji. Zdecydowano, na wniosek ks. prałata Kuliga, za pośrednictwem ks. Andrzeja Milońskiego, proboszcza parafii na Piasku, poprosić zarząd miasta, o jak najszybsze zakończenie realizowanych prac. Niemal dwa miesiące później, w listopadzie 1937 roku, prezes KTD zawiadomił Radę, że odnowiony ołtarz miał być już w najbliższych dniach udostępniony. Poinformował także, iż na jego prośbę Zakłady Graficzne „Kuriera Codziennego” sporządziły bezinteresownie fotografię ołtarza i reprodukowały ją w czasopiśmie „Światowid”"86. Zaplanowano, że na koszt Towarzystwa wykonane zostaną obrazki i kartki pocztowe przedstawiające obraz Matki Boskiej na tle Bramy, na odwrocie zamieszczona miała być modlitwa „do tejże Matki Boskiej pochodząca z dawnych lat”. Czuwający przy ołtarzu starcy mieli je sprzedawać na korzyść Towarzystwa. Na posiedzeniu odbytym 12 grudnia 1938 roku poinformowano, że obrazki zostały wykonane przez firmę Cebulskiego usytuowaną przy ulicy Szewskiej w cenie 150 zł za 10000 sztuk $^{87}$.

${ }^{84}$ ANK, Zespół KTD, Protokoły posiedzeń z lat 1921-1940, sygn. 547/11, k. 321. Protokół posiedzenia Rady Ogólnej Towarzystwa Dobroczynności w Krakowie z dnia 27 IX 1937 r. W dniu 26 VII 1937 r. dr L. Schneider wysłał list do prezesa KTD, w którym przedstawił przeszkody w umieszczeniu ołtarza, wynikające głównie z trwającej nadal restauracji Bramy. W nawiązanej dyskusji wyrażano ubolewanie, „że Zarząd miasta nie może doprowadzić do końca restauracji Bramy Floriańskiej, mimo że wymaga to z pewnością minimalnych wkładów".

${ }^{85}$ Ibidem, k. 322. Protokół posiedzenia Rady Ogólnej Towarzystwa Dobroczynności w Krakowie $\mathrm{z}$ dnia 27 IX $1937 \mathrm{r}$.

${ }^{86}$ Ibidem, k. 346. Protokół posiedzenia Rady Ogólnej Towarzystwa Dobroczynności w Krakowie z dnia 8 XI 1937 r.; M. Korczyńska-Derkacz, Problematyka kulturalna na tamach tygodnika ilustrowanego „Światowid” (1924-1939) [w:] Ilustrowany Kurier Codzienny..., s. 239, 240. Z informacji redakcji czasopisma wynikało, że po jego utworzeniu 9 VIII 1924 r. miało ono być dostępne w Krakowie, Poznaniu, Warszawie, Lwowie i Wilnie. Zawierać miało kronikę ciekawych wydarzeń, m.in. informacje o zabytkach. Zamieszczenie tam fotografii ołtarza umożliwiało upowszechnienie informacji o jego odnowieniu i stanie obecnym na rozległych terenach.

${ }^{87}$ Ibidem, k. 351. Protokół posiedzenia Rady Ogólnej Towarzystwa Dobroczynności w Krakowie z dnia 12 XII 1938 r. 


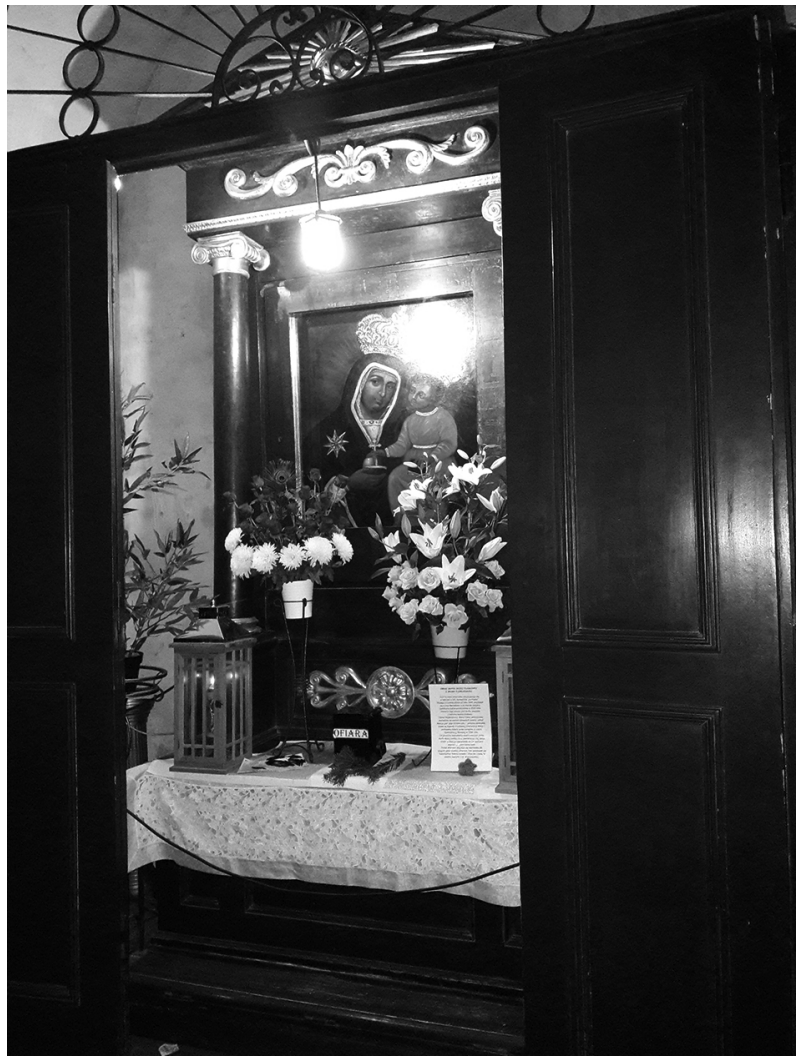

Il. 3. Ołtarz i obraz Matki Boskiej w Bramie Floriańskiej (fotografia współczesna) Źródło: ze zbiorów autorki.

O skali podejmowanych prac konserwacyjnych pisano w kronice konserwatorskiej „Rocznika Krakowskiego” z 1936 roku. Czytamy tam, że prace konserwacyjne, jakie wykonano w latach 30. XX wieku w obrębie Bramy Floriańskiej objęły odnowienie dachu i hełmu (jesień 1935 r.), które pokryto blachą miedzianą, a dach blachówką holenderską. Kolejne prace podjęto w czerwcu 1936 roku, a ich postęp opisano następująco:

Zaczęto od najwyższego piętra ceglanego, wymieniając zetlałą cegłę, oczyszczając spoiny itd. W miarę wykończenia jednej kondygnacji będzie robota postępowała dalej w dół i zakończy się odnowieniem przejazdu i znajdującego się tam ołtarza. Przewiduje się tu założenie żelaznej kraty zamiast dzisiejszego zamknięcia pełnemi drzwiami ołtarza, a to w tym celu, aby i w porze nocnej przejazd $\mathrm{w}$ bramie nie był pozbawiony malowniczego efektu ${ }^{88}$.

${ }^{88}$ B. Treter, Kronika konserwatorska, ,Rocznik Krakowski” 1936, t. XXVII, s. 186. 
W kolejnym tomie „Rocznika Krakowskiego” odnotowano, że do pilnych zadań konserwatorskich zaliczono uporządkowanie dolnych partii Bramy Floriańskiej wraz z przyległymi murami miejskimi i Basztą Stolarską ${ }^{89}$. Jak wynika z zawartych tam treści, troska o Bramę polegała również na blokowaniu niektórych planów dotyczących rozbudowy przyległych kamienic, których właściciele podejmowali próby dobudowania na przykład piętra domu. Słusznie zauważano, iż działania takie mogły wpłynąć ujemnie na wizerunek ulicy i samej Bramy Floriańskiej ${ }^{90}$. „W dniu dzisiejszym w notce informacyjnej, zamieszczonej przy ołtarzu w Bramie Floriańskiej, jest podane, że Krakowskie Towarzystwo Dobroczynności opiekowało się tym ołtarzem i obrazem Matki Boskiej przez wiele lat”.

\section{ZAKOŃCZENIE}

Podsumowując, należy zaznaczyć, że Krakowskie Towarzystwo Dobroczynności, opisane w nielicznych opracowaniach jako zajmujące się starcami i dziećmi było także opiekunem obrazu i ołtarza w Bramie Floriańskiej. Początki tej opieki sięgają roku 1817, kiedy to Senat Rzeczypospolitej Krakowskiej przekazał Towarzystwu prawo opieki oraz utrzymywania skarbony na jałmużnę dla swoich podopiecznych przy ołtarzu. Jak wynika z analizowanych dokumentów źródłowych, dzieje obrazu i ołtarza wpisują się w historię Bramy Floriańskiej, zwłaszcza jej planów rozburzania. Próby ratowania Bramy przed zniszczeniem to również walka o kapliczkę i troska o jej stan. W książeczce pt. Pieśni do najsłodszego serca Pana Jezusa ks. Michała Mycielskiego T.J. w Kempten w roku $1878^{91}$ zamieszczono pieśń na cześć Matki Boskiej w Bramie Floriańskiej, a upowszechnił ją Leon Cyfrowicz w broszurze wydanej latach 80. XIX wieku.

Należy również podkreślić, że o pomoc w określeniu wartości, jak również odnowieniu obrazu i ołtarza, zwracano się do znanych malarzy i architektów krakowskich. Ważne jest, że pomimo braku potwierdzenia przez nich wartości historycznej i artystycznej tegoż obrazu Rada Ogólna KTD dokładała starań, aby był on restaurowany. Zwracano uwagę na potrzeby duchowe osób, które przechodząc przez Bramę Floriańską, prosiły o pomoc i wsparcie Matki Boskiej. Nie bez znaczenia dla funduszów KTD były także wpływy ze znajdującej się tam skarbony, które przeznaczano na potrzeby podopiecznych oraz na kwiaty i oświetlenie obrazu. W kolejnych latach dokładano starań, aby otoczony szacunkiem i często odwiedzany przez mieszkańców i podróżnych wizerunek Matki Boskiej nie uległ zniszczeniu. Na kartach jego historii zapisały się nie tylko osoby znane z imienia i nazwiska, ale również anonimowi dobroczyńcy poświęcający siły i środki na jego odnawianie. Krakowskie Towarzystwo

89 J. Remer, Kronika konserwatorska, ,Rocznik Krakowski” 1938, t. XXX, s. 253.

90 B. Treter, op. cit., s. 185.

${ }_{91}$ L. Cyfrowicz, op. cit., s. 22, 47. Pieśń do N. Panny Maryi w bramie Floriańskiej w Krakowie. Pieśń śpiewać należało na melodię „Matko Niebieskiego Pana”. 
Dobroczynności zostało zmuszone przez władze komunistyczne do przerwania działalności, ale w Bramie Floriańskiej nadal można złożyć przy ołtarzu ofiarę dla ubogich do znajdującej się tam skarbony. Przejście przez Bramę Floriańską otwiera wnętrze ulicy Floriańskiej. Jak podkreślił Zbigniew Wzorek osobie spacerującej, w zależności od etapu tzw. trasy królewskiej, towarzyszy zmienność nastroju. Obserwowane zabytki stanowią niewyczerpane źródło kontemplacji i analizy. Autor zaznaczył, że kontakt z zasobami kultury i znajomość dziejów stwarzają „sposobność do przeżyć ogółowi zwiedzających"92. Działania podejmowane przez członków Krakowskiego Towarzystwa Dobroczynności, w ramach pełnionej opieki nad obrazem i ołtarzem w Bramie Floriańskiej, stanowią pewien etap w trosce o zachowanie tych dóbr.

\section{BIBLIOGRAFIA}

\section{Źródła archiwalne}

Archiwum Narodowe w Krakowie

Akta obrazu Matki Boskiej w Bramie Floriańskiej będącego pod opieką Towarzystwa Dobroczynności 1817-1945, sygn. 547/427, rękopis.

Protokół pierwszy posiedzeń Towarzystwa Dobroczynności w Krakowie od 1816 do 1827, sygn. 547/ 1 (dawna: TD 7), rękopis.

Protokoty posiedzeń z lat 1921-1940, sygn. 547/11 (dawna: TD 320), maszynopis.

Urząd Wojewódzki Krakowski, sygn. UW II 1098, Rejestracja stowarzyszeń z terenu Krakowa 1945-1950 (1951), maszynopis.

\section{Źródła drukowane}

Brzozow ski S., Józef Kremer jako pisarz, filozof i estetyk. Szkic krytyczny, Warszawa 1902. Cyfrowicz L., Obraz Matki Boskiej i skarbonka ubogich w Bramie Floryańskiej w Krakowie, Kraków 1884.

Dawne zabytki miasta Krakowa. Przypomnienia przeszłości o niektórych starożytnych zwyczajach mieszczan krakowskich. O bramach, basztach $i$ wszelakich tej niegdyś stolicy kraju obronach, z dodatkiem różnych do dziedziny pamiątek należacych wiadomości. Z rękopisów zebrat i ogłosił Ambroży Grabowski, Kraków 1850.

Głębocki J.T., Zakłady ku ulżeniu cierpieniom bliźnich obecnie w Krakowie istniejace. $Z$ krótka wzmianką o dawniejszych, a dziś nie istniejących instytucyach tego rodzaju, Kraków 1852.

Historye cudownych obrazów Najświętszej Maryi Panny w Polsce zebrał wedlug autentycznych źródet ks. Alojzy Fridrich T.J., tom drugi obejmujący obrazy dyecezyi krakowskiej, archidyecezyi lwowskiej, dyecezyi przemyskiej i tarnowskiej, Kraków 1904.

Kopera F., Historya architektury, „Rocznik Krakowski” 1904, t. VI, s. 70-144.

92 Z. Wzorek, Cracovia Totius Poloniae Urbs Celeberimma, „Teka Komisji Urbanistyki i Architektury" 1983, t. XVII, s. 10, 13. 
Kremer J., Kraków wobec Polski i Sukiennice jego oraz słowo o Bramie Floriańskiej, Kraków 1870.

Nowakowski W., O cudownych obrazach w Polsce Przenajświętszej Matki Bożej wiadomości historyczne, bibliograficzne i ikonograficzne przez X. Wacława z Sulgostowa, Kraków 1902.

Organizacja i ustawy Towarzystwa Dobroczynności Wolnego Miasta Krakowa, Kraków 1817.

Pamiętnik Towarzystwa Dobroczynności Krakowskiego wydanym z powodu obchodzonego $w$ d. 24 i 25 czerwca 1866 r. pięćdziesiąt-letniego Jubileuszu wskrzeszenia w roku 1816 tegoż Towarzystwa, Kraków 1868.

Radwański J., O Bramie Floriańskiej i o Serbach, Kraków 1832.

Remer J., Kronika konserwatorska, „Rocznik Krakowski” 1938, t. XXX, s. 249-264.

Rocznik XIII Towarzystwa Dobroczynności Wolnego Miasta Krakowa za rok 1830, Kraków 1831.

Rocznik XXII Towarzystwa Dobroczynności Wolnego Miasta Krakowa, Kraków 1841.

Rocznik XXXII Towarzystwa Dobroczynności Miasta Krakowa z roku 1850, Kraków 1851.

Rocznik XLII Towarzystwa Dobroczynności Miasta Krakowa z roku 1860, Kraków 1861.

Rocznik LVII Krakowskiego Towarzystwa Dobroczynności z roku 1875, Kraków 1876.

Rocznik LXIII Krakowskiego Towarzystwa Dobroczynności z roku 1881, Kraków 1882.

Rocznik LXXIII Krakowskiego Towarzystwa Dobroczynności z roku 1891, Kraków 1892.

Uroczyste zamknięcie kuli z Bramy Floriańskiej, „Ilustrowany Kurier Codzienny”, 5 VIII 1936 r., nr 216, s. 17-18.

Wiadomości o czynnościach Wileńskiego Towarzystwa Dobroczynności od czasu jego utworzenia do dnia 1 stycznia 1819 r. przez Sekretarza Towarzystwa Ignacego Jundziłła ułożona, Wilno 1819 .

\section{Artykuły w czasopismach}

Barnaś E., Powstanie i pierwsze lata działalności Krakowskiego Towarzystwa Dobroczynności (1816-1820), „Zeszyty Naukowe WSP w Rzeszowie. Pedagogika. Psychologia” (Rzeszów) 1997, z. 3, s. 87-99.

Barnaś-Baran E., Działalność opiekuńcza Krakowskiego Towarzystwa Dobroczynności w latach 1919-1939, „Studia i Prace Pedagogiczne” (Lublin) 2015, nr 2, s. 213-224.

Bąk J., Opieka społeczna nad sierotami w Krakowskim Towarzystwie Dobroczynności w latach 1816-1916, „Rocznik Krakowski” (Kraków) 1975, t. 46, s. 99-112.

Markiewiczow H., Działalność Wileńskiego Towarzystwa Dobroczynności w poczatkach XIX stulecia, „Kultura i Edukacja” (Warszawa) 1993 nr 3, s. 117-124.

Markiewiczowa H., Działalność wychowawczo-opiekuńcza Warszawskiego Towarzystwa Dobroczynności w latach 1814-1914, „Przegląd Historyczno-Oświatowy” (Warszawa) 1990 R. 33, nr 2, s. 196-206.

Reinhard-Chlanda M., Witraż w kaplicy Bramy Floriańskiej, „Rocznik Krakowski” (Kraków) 2008, t. 74, s. 191-201.

Skowron R., Towarzystwo Dobroczynności. Organizacja i działalność ogólnego domu schronienia ubogich na Wawelu (1816-1846), „Studia do Dziejów Wawelu” (Kraków), R. V, 1991 s. 479-496.

Sułecki S., Gałka na karmelitańskiej kaplicy Matki Bożej Pisakowej w Krakowie, „Krakowski Rocznik Archiwalny" (Kraków) 2007, t. 13, s. 175-189. 
Swaryczewski A., Poludniowo-zachodni odcinek murów obronnych Krakowa, „Teka Komisji Urbanistyki i Architektury" (Kraków) 1975, t. IX, s. 25-42.

Treter B., Kronika konserwatorska, „Rocznik Krakowski” (Kraków) 1936, t. XXVII, s. $177-189$.

Wrorek Z., Cracovia Totius Poloniae Urbs Celeberimma, „Teka Komisji Urbanistyki i Architektury" (Kraków) 1983, t. XVII, s. 9-15.

\section{Opracowania}

Bańdo A., „Ilustrowany Kurier Codzienny” - pierwsze nowoczesne polskie pismo masowe [w:] Ilustrowany Kurier Codzienny. Ksiega pamiatkowa w stulecie powstania dziennika i wydawnictwa 1910-1939, red. G. Wrona, P. Borowiec, K. Woźniakowski, Kraków 2010.

Bańdo A., Nie tylko krew na pierwszej stronie. Problematyka kulturalna na łamach ,Ilustrowanego Kuriera Codziennego" w latach 1918-1939, Kraków 2006.

Borowiec P., Jesteśmy głosem milionów. Dzieje krakowskiego wydawnictwa i koncernu prasowego Ilustrowany Kurier Codzienny (1910-1939), Kraków 2005.

Dzieje Krakowa, red. J. Bieniarzówna, J.M. Małecki, J. Mitkowski, t. 3: Kraków w latach 1796-1918, red. J. Bieniarzówna, J.M. Małecki, Kraków 1997.

Dzieje Krakowa, red. J. Bieniarzówna, J.M. Małecki, t. 4: E. Adamczyk [et al.], Kraków w latach 1918-1939, Kraków 1997.

Encyklopedia Krakowa, red. A.H. Stachowski, Kraków 2000.

Kępski C., Lubelskie Towarzystwo Dobroczynności (1815-1952), Lublin 1990.

Kołodziej J., Krakowskie tramwaje, Rybnik 2010.

Korczyńska-Derkacz M., Problematyka kulturalna na łamach tygodnika ilustrowanego „Światowid” (1924-1939) [w:] G. Wrona, P. Borowiec, K. Woźniakowski, Ilustrowany Kurier Codzienny. Księga pamiątkowa w stulecie powstania dziennika i wydawnictwa 1910-1939, Kraków 2010.

Kukiel M., Czartoryski Władysław, książe (1828-1894) [w:] Polski Słownik Biograficzny 1938, t. IV, s. 300-303.

Pachoński J., Dawne mury floriańskie. Zarys historyczny fortyfikacji i organizacji obrony miasta oraz przewodnik po wystawie „Dawne warownie Krakowa”, Kraków 1955.

Panek B., Krakowskie organizacje charytatywne w latach 1918-1939, Kraków 1986.

Puszka A., Działalność opiekuńczo-wychowawcza Zakonu Sióstr Miłosierdzia Wincentego à Paulo w Lublinie w XIX i XX wieku, Lublin 2013.

Widacka-Bisaga A., Między pobożnościq a przesądem. Matka Boska Piaskowa a fenomen cudownych wizerunków maryjnych w Polsce, Kraków 2013. 
